\title{
Performa Produksi dan Reproduksi Ayam Sentul dengan Konsentrasi IgY Berbeda dalam Serum Darah
}

\author{
Production Performances and Reproduction of Sentul Cocks with Different IgY Concentrations in Blood \\ Serum
}

\author{
R. Ariyanti ${ }^{1}$, N. Ulupi ${ }^{2}$, T. Suryati ${ }^{2}$, R. I. Arifiantini ${ }^{3}$ \\ ${ }^{1}$ Mahasiswa Pascasarjana Program Studi Ilmu Produksi dan Teknologi Peternakan \\ ${ }^{2}$ Departemen Program Studi Ilmu Produksi dan Teknologi Peternakan \\ ${ }^{3}$ Departemen Klinik, Reproduksi dan Patologi, Fakultas Kedokteran Hewan IPB \\ Fakultas Peternakan Institut Pertanian Bogor \\ Jln. Agatis, Kampus IPB Dramaga, Bogor, 16680, Indonesia \\ No.Telp : +62 82375568291 Email : ria ariyant@yahoo.co.id
}

\begin{abstract}
This study was aimed to evaluate the effect of different IgY concentrations on the production performance and quality of semen sentul cocks with different total IgY in serum. This research used 20 sentul cocks with 4 month age consisted of 10 cocks with high IgY concentration and 10 cocks with low IgY concentration. Variabels observed included production performance (feed consumption, weight gain of feed conversion, final body weight, mortality) and quality semen (macroscopic and microscopic). Study was designed using completely randomized design (RAL) with 2 treatments. All treatments were repeated 10 times. The results started that IgY concentrations treatment did not affect DMA production performance and quality of semen, but signicantly affecting $(p<0.05)$ mass movement of spermatozoa.
\end{abstract}

Keywords: ayam sentul, IgY, performance, reproduction

\section{PENDAHULUAN}

Ayam lokal merupakan komoditas ternak yang paling banyak dibudidayakan oleh masyarakat Indonesia di wilayah pedesaan. Ayam lokal sudah teridentifikasi sebanyak 31 rumpun (Nataamidjaya 2010). Jumlah populasi ayam lokal di Indonesia tercatat sebanyak 298,67 juta ekor (Direktorat Jendral Peternakan 2016). Ayam lokal Indonesia berpotensi sebagai penghasil daging dan telur. Pelestarian dan pengembangan ayam lokal dapat dilakukan dengan meningkatkan kualitas bibit yang dihasilkan. Pejantan memiliki peranan yang sangat besar dalam menghasilkan keturunan dan meningkatkan performa generasi berikutnya baik performa produksi maupun performa reproduksi.

Ketahanan tubuh merupakan adalah semua mekanisme untuk mempertahankan tubuh dari berbagai macam penyebab penyakit baik dari dalam maupun luar tubuh. Berbagai penyebab seperti bakteri, virus, jamur, asap, iritan, debu, bahan organik maupun anorganik yang dijumpai di lingkungan sekitar ternak. Ketahanan tubuh yang tinggi dapat menghasilkan performa yang baik. Hal ini karena daya tahan tubuh erat kaitannya dengan sistem kekebalan tubuh yang ditunjang oleh fungsi sel imun serta produksi antibodi. Sistem pertahanan yang semakin baik, maka sistem imun tubuh juga semakin tangguh melawan berbagai agen infeksi (Regar et al. 2013).
IgY (Immunoglobulin Yolk) merupakan substansi yang diidentifikasi sebagai molekul protein dalam serum yang dapat menetralkan sejumlah mikroorganisme penyebab penyakit. IgY juga sering disebut sebagai antibodi. Total konsentrasi antibodi pada serum darah ayam adalah 5-15 $\mathrm{mg} / \mathrm{mL}$ (Gaetani et al. 2017). Namun efektivitas penggunaan IgY pada performa ayam lokal belum banyak diketahui. Berdasarkan hal tersebut maka dilakukan pengamatan untuk mengevaluasi performa ayam sentul dengan konsentrasi IgY berbeda.

\section{MATERI DAN METODE}

Penelitian ini terdiri dari 2 pengamatan dengan 10 ulangan dan setiap ulangan terdiri dari 1 ekor ayam sentul jantan. Penelitian dilakukan dengan 3 tahap yaitu: pengujian konsentrasi IgY pada serum darah dengan metode elisa, pengukuran performa produksi, dan pengamatan kualitas semen.

Tahap 1 : Pengujian konsentrasi IgY dalam serum darah Pengujian total $\operatorname{IgY}$ dilakukan pada 20 ekor ayam sentul jantan yang dilakukan dengan uji elisa. Total IgY dari keseluruhan sampel dirata-ratakan kemudian didapatkan hasil sebesar 9,30 $\pm 0,45 \mathrm{mg} \mathrm{mL} \mathrm{mL}^{-1}$. Ayam yang memiliki konsentrasi IgY di atas rata-rata dikelompokkan sebagai ayam dengan konsentrasi IgY tinggi sedangkan ayam yang 
memiliki konsentrasi IgY di bawah rata-rata dikelompokan sebagai ayam dengan konsentrasi IgY rendah.

\section{Tahap 2: Pengukuran performa produksi}

Pengamatan dimulai dengan pemeliharaan ayam sentul jantan sebanyak 20 ekor pada kandang individu yang berukuran 40x60x60 $\mathrm{cm}^{3}$ dan setiap kandang berisi 1 ekor ayam. Pakan yang digunakan adalah pakan komersial fase layer dengan bentuk crumble dengan kandungan protein 16$18 \%$. Pemberian air minum dan pakan dilakukan sebanyak 2 kali (pagi dan sore hari) secara ad libitum.

\section{Tahap 3: Pengamatan kualitas semen}

Pengamatan semen dimulai dengan melakukan penyembelihan ayam sentul jantan (postmortem) dan kemudian dilakukan tahap nekropsi. Semen diambil dari saluran vas deferens kemudian dilakukan evaluasi secara makroskopis maupun mikroskopis.

\section{Peubah yang diamati}

\section{Performa Produksi}

\section{Konsumsi pakan}

Konsumsi pakan (g), diukur berdasarkan jumlah pakan yang diberikan dikurangi jumlah pakan yang sisa pada hari tersebut.

\section{Pertambahan bobot badan}

Pertambahan bobot badan (g), diukur dengan menghitung selisih dari bobot akhir dengan bobot awal ayam sentul pada setiap minggu.

\section{Konversi pakan (Ambara et al. 2013)}

Konversi pakan, diukur dengan cara membagi jumlah pakan yang dikonsumsi dengan pertambahan bobot badan selama observasi.

\section{Bobot badan akhir}

Bobot badan akhir (g), diukur dengan menimbang ayam diakhir observasi.

\section{Mortalitas}

Mortalitas (\%), diukur dengan menghitung jumlah ayam yang mati dibagi jumlah ayam yang hidup dikali seratus persen.

\section{Performa Reproduksi}

Semen dievaluasi secara makroskopis dan mikroskopis. Evaluasi secara makroskopis dilakukan terhadap warna, konsistensi dan $\mathrm{pH}$ semen. Warna dibedakan menjadi krem dan putih susu dilihat secara visual. Konsistensi semen dibedakan antara cair, kental dan sedang. $\mathrm{pH}$ semen diukur dengan menggunakan $\mathrm{pH}$ special indicator paper (merk skala 6,4-8). Evaluasi secara mikroskopis terdiri atas motilitas, gerakan massa, viabilitas dan abnormalitas spermatozoa.

Pengamatan gerakan massa spermatozoa dilakukan dengan mikroskop pembesaran 100 kali. Penilaian dilakukan dengan melihat gelombang spermatozoa dan dinilai dengan $(+3)$ jika gelombang massa tebal dan cepat berpindah tempat, $(+2)$ jika gelombang massa tebal tetapi lambat berpindah tempat, $(+1)$ jika gelombang massa tipis dan lambat berpindah tempat dan (-) jika tidak ada gelombang massa (Arifiantini 2012).

Pengamatan motilitas spermatozoa dilakukan dengan mikroskop pembesaran 400 kali. Penilaian dilakukan dengan estimasi dari 5-10 lapangan pandang dengan cara membandingkan jumlah spermatozoa yang bergerak maju ke depan dengan gerakan spermatozoa yang lain.

Pengamatan viabilitas spermatozoa dan abnormalitas spermatozoa dilakukan dengan mikroskop dengan pembesaran 400 kali. Penilaian dilakukan dengan menghitung 10 lapangan pandang dengan jumlah sel minimal $>200$ sel. Penilaian pada spermatozoa hidup tidak menyerap warna dan spermatozoa mati menyerap warna merah pada bagian kepala, sedangkan penilaian abnormalitas spermatozoa dilakukan dengan menghitung spermatozoa abnormal dan normal.

Data mengenai evaluasi semen secara makroskopis yang meliputi warna, konsistensi dan gerakan massa akan dilakukan penilaian dengan skor 1-3. Deskripsi mengenai skor penilaian evaluasi semen makroskopis disajikan pada Tabel 1.

Tabel 1. Deskripsi skor penilaian evaluasi semen makroskopis dan mikroskopis

\begin{tabular}{llll}
\hline \multirow{2}{*}{ Skor } & \multicolumn{3}{l}{ Evaluasi semen } \\
\cline { 2 - 4 } & Warna & Konsistensi & Gerakan Massa \\
\hline 1 & Krem & Cair & + \\
2 & Putih susu & Sedang & ++ \\
3 & Putih keruh & Kental & +++ \\
\hline
\end{tabular}

\section{Analisis Data}

Data diolah dengan uji-t (Matjjik dan Sumertajaya 2013). Analisis data dilakukan dengan menggunakan software minitab. Rancangan yang digunakan dalam penelitian ini adalah rancangan acak lengkap (RAL). Pengamatannya yaitu penggunaan konsentrasi IgY yang berbeda yaitu IgY tinggi dan IgY rendah dengan pengulangan sebanyak sepuluh kali. Analisis data dilakukan dengan rumus sebagai berikut:

$$
\mathrm{t}=\frac{\bar{x}_{1}-\bar{x}_{2}}{\sqrt{\frac{\left(n_{1}-1\right) s_{1}^{2}+\left(n_{2}-1\right) s_{2}^{2}}{n_{1}+n_{2}}\left(\frac{1}{n_{1}}+\frac{1}{n_{2}}\right)}}
$$

Keterangan:

$\mathrm{n}_{1}$ : jumlah pengamatan performa dan kualitas spermatozoa IgY tinggi

$\mathrm{n}_{2}$ : jumlah pengamatan performa dan kualitas spermatozoa IgY rendah

$\mathrm{X}_{1}$ : rataan sampel performa dan kualitas spermatozoa IgY tinggi

$\mathrm{x}_{2}$ : rataan sampel performa dan kualitas spermatozoa IgY rendah

$\mathrm{s}_{1}$ : standar deviasi performa dan kualitas spermatozoa IgY tinggi

$\mathrm{s}_{2}$ : standar deviasi performa dan kualitas spermatozoa IgY rendah 


\section{HASIL DAN PEMBAHASAN}

\section{Performa Produksi Ayam Sentul Jantan}

Periode prelayer merupakan periode dimana ayam sedang menuju fase persiapan produksi sedangkan periode layer adalah periode ayam telah memasuki masa produksi (produksi semen). Pengamatan performa produksi prelayer dilakukan selama 2 bulan pada umur 4-6 bulan dan periode layer selama 1 bulan pada umur 6-7 bulan. Parameter performa produksi periode prelayer dan layer adalah konsumsi pakan, pertambahan bobot badan dan konversi pakan sedangkan pada periode layer meliputi konsumsi pakan, bobot badan awal, pertambahan bobot badan, bobot badan akhir, konversi pakan, dan mortalitas ayam. Performa produksi pada ayam lokal mempunyai arti penting dalam pemeliharaan. Hal ini berkaitan dengan kemampuan ayam lokal dalam memaksimalkan produksi cukup terbatas sebagai akibat dari rendahnya mutu genetik dan tingginya prevalensi penyakit (Pagala et al. 2013). Hasil analisis performa prelayer dan layer ayam sentul jantan hasil penelitian disajikan pada Tabel 3.

\section{Konsumsi Ransum}

Hasil observasi menunjukkan bahwa konsumsi ransum ayam sentul jantan fase prelayer selama 8 minggu berkisar antara 122,87 $\pm 3,38$ (g/ekor/hari) sampai 123,60 \pm 1,83 (g/ekor/hari) dan fase layer selama 4 minggu berkisar antara 122,97 $\pm 0,47$ (g/ekor/hari) sampai 123,00 $\pm 3,38$ (g/ ekor/hari) (Tabel 2). Hasil analisis statistik pada konsumsi ransum ayam sentul jantan dengan IgY berbeda pada fase prelayer dan layer tidak menunjukkan adanya perbedaan $(\mathrm{P}>0,05)$. Hal ini disebabkan oleh tidak berbedanya konversi pakan dan bobot badan karena selama fase prelayer ayam dalam kondisi sehat meskipun konsentrasi IgY yang berbeda di dalam tubuhnya berbeda. Terjadinya penurunan konsumsi pakan pada ayam yang memiliki IgY rendah dari fase prelayer ke fase layer disebabkan oleh adanya 30\% ayam yang terserang penyakit. Menurut Moritz et al. (2001) menyatakan bahwa ayam yang memiliki ketahanan tubuh tinggi terhadap penyakit cenderung memiliki konsumsi pakan yang baik.

Suhu lingkungan yang sama pada setiap kandang juga menyebabkan konsumsi pakan pada ayam yang memiliki IgY berbeda relatif sama . Suhu rata-rata yang terdapat pada kandang berkisar antara $25-28{ }^{\circ} \mathrm{C}$ yang masih berada pada kisaran suhu termonetral untuk pemeliharaan ayam sehingga tidak menimbulkan cekaman yang dapat memicu terjadinya fiscal regulation sehingga tidak berdampak pada perbedaan konsumsi ransum yang signifikan. Bell and Weaver (2002) menyatakan suhu lingkungan yang nyaman untuk ayam berkisar antara $20-24{ }^{\circ} \mathrm{C}$. Konsumsi ransum ayam sangat dipengaruhi oleh tinggi rendahnya suhu udara pada lingkungan. Semakin tinggi suhu udara maka ratarata panas yang dikeluarkan tubuh ayam relatif rendah dari pada yang diterima. Hal ini akan menyebabkan terjadinya peningkatan suhu tubuh dan ternak akan mengalami stres panas yang diikuti dengan penurunan konsumsi.

\section{Bobot Badan Ayam}

Hasil analisis statistik pada bobot badan awal, pertambahan bobot badan dan bobot badan akhir ayam sentul jantan dengan IgY berbeda pada fase prelayer dan layer tidak menunjukkan adanya perbedaan $(\mathrm{P}>0,05)$. Hal ini disebabkan oleh tidak berbedanya konsumsi dan konversi pakan selama proses pemeliharaan. Bobot badan merupakan salah satu indikator yang dapat menggambarkan keberhasilan selama pemeliharaan. Faktor-faktor yang mempengaruhi bobot badan ayam diantaranya adalah manajemen pemeliharaan, bibit, pakan dan kondisi lingkungan. Pertambahan bobot badan ayam mengalami penurunan dari fase prelayer ke fase layer dari pengamatan kedua konsentrasi IgY yang berbeda. Penurunan ini disebabkan oleh pakan yang dikonsumsi ayam digunakan untuk pembentukan jaringan tubuh dan bereproduksi dimana bobot badan sangat dipengaruhi oleh konsumsi ransum.

\section{Konversi Ransum}

Konversi ransum merupakan perbandingan antara jumlah ransum yang dikonsumsi dengan berat

Tabel 2. Performa produksi ayam sentul dengan IgY rendah dan IgY tinggi pada fase pre layer dan layer (Rataan \pm SD)

\begin{tabular}{lcc}
\hline \multicolumn{1}{c}{ Performa produksi } & IgY \\
\cline { 2 - 3 } & rendah $\left(\leq 9,30 \pm 0,45 \mathrm{mg} \mathrm{mL}^{-1}\right)$ & tinggi $\left(>9,30 \mathrm{mg} \mathrm{mL}^{-1}\right)$ \\
\hline Pre layer & $123,60 \pm 1,83$ & $122,87 \pm 3,38$ \\
Konsumsi pakan (g/ekor/hari) & $1877,00 \pm 165$ & $1851,00 \pm 210$ \\
Bobot badan awal (g) & $14,30 \pm 2,59$ & $15,98 \pm 3,86$ \\
Pertambahan bobot badan (g/ekor/hari) & $2490,00 \pm 121$ & $2472,00 \pm 182$ \\
Bobot badan akhir (g) & $9,08 \pm 1,73$ & $8,36 \pm 1,15$ \\
Konversi pakan & 0 & 0 \\
Mortalitas ayam (\%) & $122,97 \pm 0,47$ & $123,00 \pm 3,38$ \\
Layer & $11,34 \pm 1,94$ & $10,98 \pm 1,80$ \\
Konsumsi pakan (g/ekor/hari) & $11,88 \pm 3,12$ & $11,57 \pm 1,95$ \\
Pertambahan bobot badan (g/ekor/hari) & $2686,00 \pm 173$ & $2735,00 \pm 79,2$ \\
Konversi pakan & 0 & 0 \\
Bobot badan akhir (g) & & \\
Mortalitas ayam (\%) & & \\
\hline
\end{tabular}


Tabel 3. Karakteristik semen makroskopis ayam sentul dengan IgY rendah dan IgY tinggi (Rataan \pm SE)

\begin{tabular}{lcc}
\hline Karakteristik semen & \multicolumn{2}{c}{$\operatorname{IgY}$} \\
\cline { 2 - 3 } & $\begin{array}{c}\text { rendah }(\leq 9,30 \pm \\
0,45 \mathrm{mg} \mathrm{mL}-1)\end{array}$ & $\begin{array}{c}\text { tinggi }(>9,30 \mathrm{mg} \\
\mathrm{mL}-1)\end{array}$ \\
\hline pH semen & $7,35 \pm 0,16$ & $7,26 \pm 0,11$ \\
Warna semen & $1,88 \pm 0,13$ & $1,63 \pm 0,18$ \\
Konsistensi semen & $2,75 \pm 0,25$ & $1,88 \pm 0,35$ \\
\hline
\end{tabular}

Keterangan: Warna semen; krem (1), putih susu (2), putih keruh (3), Konsistensi semen; cair (1), sedang (2), Kental (3)

badan akhir ayam sentul jantan dengan konsentrasi IgY berbeda. Konversi ransum ayam sentul jantan pada fase prelayer berkisar antara 8,36 $\pm 1,15$ sampai $9,08 \pm 1,73$ dan fase layer berkisar antara 11,57 $\pm 1,95$ sampai 11,88 $\pm 3,12$. Hasil analisis statistik memperlihatkan bahwa IgY berbeda pada ayam sentul jantan fase prelayer dan layer tidak menunjukkan adanya perbedaan $(\mathrm{P}>0,05)$. Hal ini disebabkan oleh pada fase prelayer pertambahan bobot badan ayam sentul jantan juga tidak berbeda. Meskipun konversi pakan pada kedua pengamatan tidak berbeda tetapi konversi pakan ayam sentul jantan yang memiliki IgY tinggi lebih baik dibandingkan dengan konversi pakan pada ayam sentul jantan yang memiliki IgY rendah karena ayam yang memiliki IgY tinggi lebih efisien dalam mencerna pakan. Menurut Nurhayati et al. (2016) menyatakan bahwa semakin rendah konversi pakan maka ternak semakin efisien dalam merubah pakan menjadi jaringan tubuh yang akan berpengaruh terhadap penurunan biaya produksi selama pemeliharaan.

\section{Mortalitas}

Hasil pengamatan menunjukkan bahwa mortalitas ayam sentul jantan pada konsentrasi IgY berbeda pada fase prelayer dan fase layer tidak terdapat angka mortalitas pada semua konsentrasi IgY, artinya angka mortalitas ayam sentul jantan $0 \%$ selama pengamatan berlangsung. Angka mortalitas ayam sentul jantan yang memiliki IgY berbeda yaitu $0 \%$ selama pengamatan. Hal ini menggambarkan bahwa ayam sentul jantan yang digunakan dalam pengamatan ini memiliki konsentrasi antibodi yang baik yaitu berkisar antara $9 \mathrm{mg} / \mathrm{mL}$ sampai $14 \mathrm{mg} / \mathrm{mL}$. Hal ini sesuai dengan pendapat Gaetani et al. (2017) yang menyatakan bahwa total antibodi pada serum darah ayam adalah 5-15 mg/mL. Meskipun pada pengamatan ini tidak ada ayam yang mati tetapi terdapat $30 \%$ ayam dari ayam yang memiliki konsentrasi IgY rendah yang terserang penyakit dengan gejala ngorok selama 3-4 hari. Menurut Soeripto (2009) menyatakan bahwa ngorok merupakan salah satu gejala penyakit chronic respiratory disease (CRD) yang menyerang saluran pernapasan pada unggas dan disebabkan oleh organisme Mycoplasma gallisepticum.

\section{Kualitas Semen Makroskopis Ayam Sentul Jantan}

Hasil pengamatan semen ayam sentul secara makroskopis menunjukkan $\mathrm{pH}$ semen yang didapat antara $7,26 \pm 0,11$ sampai 7,35 $\pm 0,16$. Hasil ini lebih tinggi daripada hasil yang didapat oleh Khaerudin et al. (2016) yaitu 7,03 \pm
Tabel 4. Karakteristik semen mikroskopis ayam sentul dengan IgY rendah dan IgY tinggi (Rataan \pm SE)

\begin{tabular}{lcc}
\hline Karakteristik semen & \multicolumn{2}{c}{$\operatorname{IgY}$} \\
\cline { 2 - 3 } & $\begin{array}{c}\text { rendah }(\leq 9,30 \pm \\
0,45 \mathrm{mg} \mathrm{mL}-1)\end{array}$ & $\begin{array}{c}\text { tinggi }(>9,30 \mathrm{mg} \\
\mathrm{mL}-1)\end{array}$ \\
\hline $\begin{array}{l}\text { Gerakan massa } \\
\text { spermatozoa }\end{array}$ & $2,50 \pm 0,19 \mathrm{a}$ & $1,63 \pm 0,32 \mathrm{~b}$ \\
$\begin{array}{l}\text { Motilitas } \\
\text { spermatozoa (\%) }\end{array}$ & $76,00 \pm 1,90$ & $72,00 \pm 2,00$ \\
$\begin{array}{l}\text { Viabilitas } \\
\text { spermatozoa (\%) }\end{array}$ & $83,09 \pm 2,60$ & $80,77 \pm 3,90$ \\
$\begin{array}{l}\text { Abnormalitas } \\
\text { spermatozoa (\%) }\end{array}$ & $25,92 \pm 2,00$ & $23,93 \pm 1,80$ \\
\hline
\end{tabular}

Keterangan : superskrip berbeda pada baris/kolom yang sama menunjukkan berbeda nyata $(\mathrm{P}<0,05)$. Gerakan massa spermatozoa; (-) buruk, (+1) sedang, (+2) baik, (+3) sangat baik

0,02 pada peranakan ayam sentul. Nilai tersebut merupakan $\mathrm{pH}$ netral pada semen ayam sentul. Derajat keasaman semen sangat berpengaruh terhadap daya hidup spermatozoa. Semakin rendah nilai $\mathrm{pH}$ maka persentase motilitasnya akan semakin rendah. Hal ini disebabkan oleh peningkatan aktivitas spermatozoa yang menguraikan fruktosa pada kondisi anaerob. Penguraian fruktosa menyebabkan terbentuknya asam laktat pada semen. Semakin banyak asam laktat yang terbentuk maka $\mathrm{pH}$ semen akan semakin rendah dan persentase mortalitasnya akan semakin tinggi.

Warna semen yang dihasilkan ayam sentul pada observasi ini adalah putih susu. Konsistensi semen yang dihasilkan adalah kental. Hal ini sesuai dengan hasil penelitian Alhmadi et al. (2014) menyatakan bahwa warna semen pada ayam normal adalah putih susu. Warna dan konsistensi semen menggambarkan konsentrasi spermatozoa yang terkandung didalamnya. Semen kental dan berwarna putih susu maka konsentrasi spermatozoa tinggi sebaliknya bila semen encer dan berwarna bening maka konsentrasi spermatozoanya rendah.

\section{Kualitas Semen Mikroskopis Ayam Sentul Jantan}

Secara mikroskopis peubah motilitas, viabilitas dan abnormalitas pada penelitian ini tidak menunjukkan adanya perbedaan yang signifikan. Hal ini disebabkan karena pada saat pengambilan semen ayam sentul jantan dalam kondisi sehat. Ayam yang sehat relatif menghasilkan produksi yang sama. Sedangkan pada peubah gerakan massa spermatozoa pada penelitian ini menunjukkan adanya perbedaan yang signifikan. Gerakan massa yang dihasilkan pada ayam sentul dengan IgY rendah $(+1)$ lebih baik dari gerakan massa yang dihasilkan ayam dengan IgY tinggi $(+2)$. Hal ini disebabkan oleh energi yang dikonsumsi ayam sentul dengan IgY rendah lebih diutamakan untuk proses produksi spermatozoa, sedangkan pada ayam sentul dengan IgY tinggi gerakan massa spermatozoa yang dihasilkan sedang. Hasil ini lebih rendah daripada penelitian Junaidi et al. (2016) bahwa gerakan spermatozoa pada ayam sentul yaitu $(+3)$. Gerakan massa spermatozoa berhubungan dengan motilitas dan konsentrasi spermatozoa. Motilitas spermatozoa yang tinggi menunjukkan gerakan massa spermatozoa yang baik 
pula. Motilitas spermatozoa ayam sentul menunjukkan nilai berkisar antara 72,00 $\pm 2,00 \%$ sampai 76,00 $\pm 1,90 \%$. Nilai tersebut sama dengan penelitian Mugiyono et al. (2016) pada ayam sentul yaitu 73,50 $\pm 4,04 \%$. Motilitas spermatozoa yang baik memungkinkan spermatozoa mencapai sel telur dengan waktu yang relatif singkat sehingga memungkinkan fertilisasi terjadi dengan sempurna.

Viabilitas spermatozoa ayam sentul berkisar antara $80,77 \pm 3,90 \%$ sampai $83,09 \pm 2,60 \%$. Hasil observasi viabilitas spermatozoa pada ayam dengan konsentrasi IgY berbeda ini lebih besar dari hasil penelitian Danang et al. (2012) pada ayam kampung yaitu 86\%. Persentase spermatozoa hidup lebih tinggi daripada spermatozoa motil yang disebabkan oleh jumlah spermatozoa hidup belum tentu semuanya motil progresif

Abnormalitas spermatozoa ayam sentul pada observasi ini berkisar antara 23,93 $\pm 1,80 \%$ sampai 25,92 \pm $2,00 \%$. Nilai ini jauh lebih tinggi dari penelitian Khaerudin et al. (2016) yaitu 6,24 $\pm 1,20 \%$. Hasil ini menunjukkan bahwa abnormalitas spermatozoa dalam observasi ini tidak dalam kisaran normal. Semen dengan persentase abnormalitas lebih dari $25 \%$ cenderung memiliki fertilitas yang rendah karena berkaitan dengan kemampuan mengawali fertilisasi (Ihsan 2009).

\section{KESIMPULAN}

Penggunaan ayam jantan yang memiliki konsentrasi IgY tinggi ( $\left.>9,30 \pm 0,45 \mathrm{mg} \mathrm{mL}^{-1}\right)$ dan konsentrasi $\mathrm{IgY}$ rendah $\left(\leq 9,30 \pm 0,45 \mathrm{mg} \mathrm{mL}^{-1}\right)$ tidak berpengaruh pada performa produksi ayam sentul jantan tetapi berpengaruh pada kualitas spermatozoa (gerakan massa) yang diambil setelah proses postmortem.

\section{DAFTAR PUSTAKA}

Almahdi, A.B., Ondho Y.S. \& Sutopo. 2014. Comparative studies of semen quality on different breed of chicken in poultry breeding center Temanggung central Java. Intl Refereed J of Engineering and Sci: 3(2):94-103.

Arifiantini, R.I. 2012. Teknik Koleksi dan Evaluasi Semen pada Hewan. Bogor (ID): Institut Pertanian Bogor Press.

Danang, D.R., N. Isnaini \& P. Trisunuwati. 2012. Pengaruh lama simpan semen terhadap kualitas spermatozoa ayam kampung dalam pengencer ringer's pada suhu 4 ${ }^{\circ} \mathrm{C}$. Jurnal Ternak Tropika: 13(1): 47-57.

[Ditjen PKH] Direktorat Jendral Peternakan dan Kesehatan Hewan. 2016. Statistik Peternakan dan Kesehatan Hewan (Livestock and Animal Health Statistics) 2016. Jakarta (ID). Kementrian Pertanian RI.

Gaetani, C., Ambrosi E., Ugo P \& Moretto M.L. 2017. Electrochemical Immuno Sensor for Detection of Immunoglobulin Yolk in Food and Food Suplements. J Chem. 5(10).

Ihsan, N.M. 2009. Bioteknologi Reproduksi Ternak. Universitas Brawijaya. Malang.

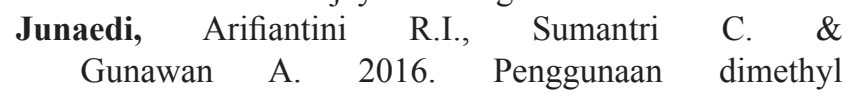

sulfoxide sebagai krioprotektan dalam pembekuan semen ayam kampung. J Vet: 17(2):300-308.

Khaeruddin, R.I. Arifiantini, C. Sumantri \& S. Darwati. 2016. Kualitas spermatozoa ayam peranakan sentul dalam pengencer ringer laktat kuning telur dengan berbagai monosakarida. Jurnal Kedokteran Hewan: 10(2): 166-169.

Mattjik, A.A. \& Sumertajaya M. 2013. Perancangan Percobaan dengan Aplikasi SAS dan Minitab Jilid I. Bogor (ID): Institut Pertanian Bogor Press.

Moritz, J.S., Beyer, R.S,, Wilson, K.J., Cramer, K.R., McKinney, L.J., Fairchild, F.J,. 2001. Effect of moisture addition at the mixer to a corn-soybean based diet on broiler performance. The Journal of Applied Poultry Research. 10:347-353.

Mugiyono, S., Dadang M.S. \& Sukardi. 2015. Reproductive Performance of Various Breeds of Sentul Chicken. J Anim Product: 17(3):169-176

Nataamidjaya, A.G. 2010. Koleksi Ayam Lokal secara ex situ dengan Memanfaatkan Informasi Bioteknis Kondisi in situ. Balai Penelitian dan Pengembangan Pertanian. Bogor.

Nurhayati, Berliana \& Nelwilda. 2016. Performa ayam broiler yang mengkonsumsi kulit nanas yang difermentasi dengan yogurt dalam ransum mengandung gulma obat. Jurnal Agripet: 16: 31-36.

Regar, N.M., Mutia R., Widhyari D.S. \& Kowel S.H.Y. 2013. Pemberian Ransum Kombinasi Herbal dengan Mineral Zink Terhadap Performan Ayam Broiler yang Diinfeksi Escherichia coli. Jurnal Zootek ("Zootek" Journal): 33(1):35-40.

Soeripto. 2009. Chronic respiratory disease pada ayam. Wartazoa. 19(3):134-142. 